\title{
CONTENT OF SOME HEAVY METALS IN BULGARIAN HONEYDEW HONEY
}

\author{
M. Marinova*, K. Gurgulova, G. Kalinova, H. Daskalov \\ National Diagnostic and Research Veterinary Medical Institute, Sofia, Bulgaria
}

\begin{abstract}
The bee honey is valuable and indispensable food that has accompanied the mankind since the ancient ages up today. Due to the specific way of deposing of the honeydew on the surface of the plant leaves, the honeydew honey is exposed on contamination from the environment on higher degree compared with the nectar honey. This study aimed to analyze the content of: lead, cadmium, copper, zinc, iron, manganese and cobalt in samples of honeydew honey from some high producing areas in Northeast (Silistra, Razgrad), and Southeast Bulgaria (Burgas).The samples were analyzed using atomic absorption spectrometer Perkin Elmer 3030. The ash content and the conductivity were determined as well. The conductivity of all samples exceeded $0.8 \mathrm{mS} / \mathrm{cm}$ - meeting the requirements for authenticity of honeydew honey. The highest results for the content of lead $(0.21 \pm 0.04) \mathrm{mg} / \mathrm{kg}$, cadmium $(0.023 \pm 0.007) \mathrm{mg} / \mathrm{kg}$, zinc $(3.29 \pm 2.34) \mathrm{mg} / \mathrm{kg}$ and manganese $(2.39 \pm 0.85) \mathrm{mg} / \mathrm{kg}$ were found in the samples from Razgrad, for copper $(0.87 \pm 0.28) \mathrm{mg} / \mathrm{kg}$ and for iron $(11.47 \pm 6.29) \mathrm{mg} / \mathrm{kg}-\mathrm{the}$ highest were in Silistra and for cobalt $(0.036 \pm 0.012) \mathrm{mg} / \mathrm{kg}$ - in Burgas. The study demonstrates that the content of investigated metals in the honeydew honey is well balanced, and does not pose a risk for the consumer.
\end{abstract}

Key words: honeydew honey, heavy metals, conductivity, ash content

\section{INTRODUCTION}

The bee honey is valuable and indispensable food that has accompanied the mankind since the ancient ages up today. It is a natural sweet product, produced by honey bees Apis mellifera from the plant nectar - nectar honey, or from the secretions of the live parts of plants and the excreta of the insects, sucking from the plants honeydew honey (1). Honey is a complex biological product, extremely valuable for the human organism as food and remedy. That is why it should not contain undesired substances like pesticides, radionuclides, residues of veterinary medical products, heavy metals. Honeydew honey is often preferred for medical purposes, as it contains greater amount of micro elements, high molecular sugars, and amino acids. It is recommended in cases of anemia, anorexia, liver diseases, viral infections and flu (2).

Studies of many authors prove the connection between the content of heavy metals in polluted

*Correspondence to: Margarita Marinova, 1606Sofia, "Pencho Slaveikov" blvd. 15, NDRVMI, Tel.: +359 887068787, Fax: +359295253 06, E-mail: magi_marinova1960@abv.bg environment and their content in the bee honey produced in this environment $(3,4,5)$. Due to the specific way of deposing of the honeydew on the surface of the plant leaves, the honeydew honey is exposed on contamination from the environment on higher degree compared with the nectar honey, especially when the contamination comes from the air. Many authors find higher values of the studied metals in honeydew honey compared with nectar honey with identical environmental conditions $(6,7)$. According to some authors, the heavy metals content is between 2 and 3 times higher than the content in nectar honey, albeit both types of honey are produced in identical environment (8). That makes the honeydew honey a good indicator whether a specific area is polluted or not. The presence of industrial pollutants close to towns and developed transportation presuppose the presence of polluted environment and a risk of higher content of metals in the honey produced in it. Even if the bee colonies are not located in areas with high anthropogenic risk, the climate conditions may be a reason for polluting the environment. This study aimed to analyze the content of seven metals: lead $(\mathrm{Pb})$, cadmium 
$(\mathrm{Cd})$, copper $(\mathrm{Cu})$, zinc $(\mathrm{Zn})$, iron $(\mathrm{Fe})$, manganese $(\mathrm{Mn})$, and cobalt $(\mathrm{Co})$ in samples of honeydew honey (after preliminary proof of its authenticity) from the areas of the following areas in Northeast (Silistra, Razgrad), and Southest Bulgaria (Burgas). Elements posing toxicological risk for people were selected - $\mathrm{Pb}, \mathrm{Cd}, \mathrm{Co}, \mathrm{Cu}$, $\mathrm{Mn}$, and $\mathrm{Zn}$. Iron was another element, selected by us for studying as it is toxic for bees (its increased content in their food results in higher levels of bee death rate).

\section{MATERIAL AND METHODS}

The study analyzed the mineral content of 44 samples of honeydew honey, produced in the areas of towns of Silistra (10 samples), Razgrad (9 samples), and Burgas (25 samples). We acquired the honey samples in the period between 2009 and 2013 from private farmers, breeding bee colonies in remote areas, away of towns and busy road system. The samples were prepared for analysis according to БДС ЕN 14082:2003 (9).

The samples were analyzed using atomic absorption spectrometer Perkin Elmer 3030 with the following wavelengths: lead $-283.3 \mathrm{~nm}$, cadmium - $228.8 \mathrm{~nm}$, copper - $327.4 \mathrm{~nm}$, zinc $213.9 \mathrm{~nm}$, iron $-248.3 \mathrm{~nm}$, manganese -279.5 $\mathrm{nm}$, and cobalt $-240.7 \mathrm{~nm}$.

The ash content was determined gravimetrically after dry ashing of the sample at $550{ }^{\circ} \mathrm{C}$.
The conductivity was determined in two ways:

- measured using a Thermo ELECTRON CORPORATION conductivity meter with Orion DuraProbe Conductivity Cells $013005 \mathrm{MD}$ electrode with $0.475 \mathrm{~cm}^{-1}$ cell constant of $20 \%$ aqueous solution of honey at $20^{\circ} \mathrm{C}$ temperature;

- calculated using the following formula, describing the linear relation between ash content and conductivity (10):

$\mathrm{C}=0.14+1.74 \mathrm{~A}$, where:

C - conductivity in $\mathrm{mS} / \mathrm{cm}$;

A - ash content in $\%$.

All results are processed statistically - mean value and standard deviation was calculated using Microsoft Excel 2007.

\section{RESULTS AND DISCUSIONS}

Table 1 shows the results of 44 samples of honeydew honey, examined for ash content, calculated conductivity (10) and measured conductivity, content of elements lead $(\mathrm{Pb})$, cadmium $(\mathrm{Cd})$, copper $(\mathrm{Cu})$, zinc $(\mathrm{Zn})$, iron $(\mathrm{Fe})$, manganese $(\mathrm{Mn})$, and cobalt $(\mathrm{Co})$.

The conductivity of all examined samples exceeded $0.8 \mathrm{mS} / \mathrm{cm}$ - meeting the requirements for authenticity of honeydew honey (1). The values of calculated and measured conductivities were similar for the three areas (Figure 1).

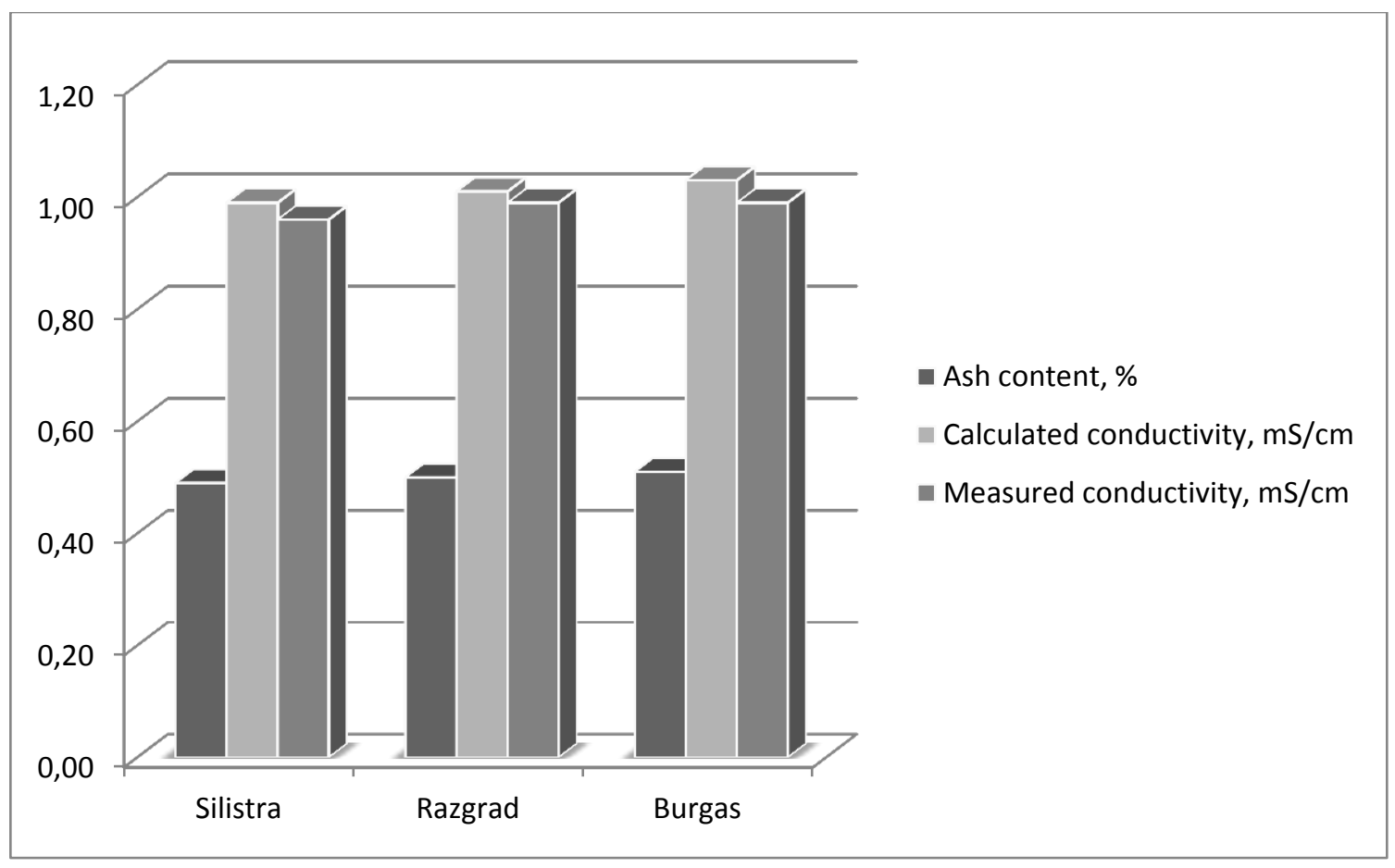

Figure 1. Ash content, calculated and measured conductivity in honeydew honey from the regions of Silistra, Razgrad and Burgas 
Table 1. Ash content, calculated and measured conductivity and content of lead, cadmium, copper, zinc, iron, manganese and cobalt in honeydew honey from the regions of Silistra, Razgrad and Burgas

\begin{tabular}{|c|c|c|c|c|c|c|c|c|c|c|c|}
\hline & & $\begin{array}{c}\text { Ash content, } \\
\%\end{array}$ & $\begin{array}{c}\text { Calculated } \\
\text { conductivity, } \\
\mathrm{mS} / \mathrm{cm}\end{array}$ & $\begin{array}{c}\text { Measured } \\
\text { conductivity, } \\
\mathrm{mS} / \mathrm{cm}\end{array}$ & $\begin{array}{l}\text { Lead, } \\
\mathrm{mg} / \mathrm{kg}\end{array}$ & $\begin{array}{l}\text { Cadmium, } \\
\mathrm{mg} / \mathrm{kg}\end{array}$ & $\begin{array}{c}\text { Copper, } \\
\mathrm{mg} / \mathrm{kg}\end{array}$ & $\begin{array}{l}\text { Zinc, } \\
\mathrm{mg} / \mathrm{kg}\end{array}$ & $\begin{array}{l}\text { Iron, } \\
\mathrm{mg} / \mathrm{kg}\end{array}$ & $\begin{array}{c}\text { Manganese, } \\
\mathrm{mg} / \mathrm{kg}\end{array}$ & $\begin{array}{l}\text { Cobalt, } \\
\mathrm{mg} / \mathrm{kg}\end{array}$ \\
\hline \multirow{3}{*}{$\begin{array}{l}\text { Silistra } \\
\mathrm{N}=10\end{array}$} & $\mathrm{X} \pm \mathrm{Sx}$ & $0.49 \pm 0.04$ & $0.99 \pm 0.07$ & $0.96 \pm 0.08$ & $0.16 \pm 0.07$ & $0.022 \pm 0.013$ & $0.87 \pm 0.28$ & $1.96 \pm 1.05$ & $11.47 \pm 6.29$ & $2.21 \pm 1.08$ & $0.034 \pm 0.007$ \\
\hline & Min & 0.41 & 0.85 & 0.82 & 0.09 & 0.007 & 0.47 & 0.83 & 6.55 & 0.71 & 0.025 \\
\hline & Max & 0.53 & 1.06 & 1.05 & 0.31 & 0.047 & 1.27 & 3.67 & 28.80 & 4.38 & 0.046 \\
\hline \multirow{3}{*}{$\begin{array}{l}\text { Razgrad } \\
\qquad N=9\end{array}$} & $\mathrm{X} \pm \mathrm{Sx}$ & $0.50 \pm 0.05$ & $1.01 \pm 0.09$ & $0.99 \pm 0.09$ & $0.21 \pm 0.04$ & $0.023 \pm 0.007$ & $0.81 \pm 0.29$ & $3.29 \pm 2.34$ & $9.66 \pm 2.84$ & $2.39 \pm 0.85$ & $0.032 \pm 0.008$ \\
\hline & Min & 0.40 & 0.84 & 0.82 & 0.12 & 0.011 & 0.23 & 1.08 & 5.15 & 1.05 & 0.021 \\
\hline & Max & 0.56 & 1.12 & 1.09 & 0.26 & 0.032 & 1.06 & 8.75 & 14.32 & 3.45 & 0.049 \\
\hline \multirow{3}{*}{$\begin{array}{l}\text { Burgas } \\
\mathrm{N}=25\end{array}$} & $\mathrm{X} \pm \mathrm{Sx}$ & $0.51 \pm 0.07$ & $1.03 \pm 0.12$ & $0.99 \pm 0.12$ & $0.11 \pm 0.03$ & $0.018 \pm 0.008$ & $0.84 \pm 0.30$ & $1.06 \pm 0.46$ & $5.44 \pm 1.47$ & $2.02 \pm 1.08$ & $0.036 \pm 0.012$ \\
\hline & Min & 0.40 & 0.84 & 0.81 & 0.09 & 0.006 & 0.29 & 0.63 & 3.42 & 0.34 & 0.023 \\
\hline & $\operatorname{Max}$ & 0.71 & 1.37 & 1.32 & 0.21 & 0.031 & 1.59 & 2.42 & 8.15 & 3.75 & 0.067 \\
\hline
\end{tabular}


Probably it is in relation with the similar type of forests (oak trees, hornbeam trees and linden trees). In the area of Burgas the maximal values of conductivity and ash content are slight higher than the respective values in the other two areas $-1.32 \mathrm{mS} / \mathrm{cm}$ conductivity and $0.71 \%$ ash, probably due to the following trees, growing in Strandja: beech trees, oak trees (Q. stranjensis); and durmast trees. The average conductivity values from the three areas $(0.96-0.99) \mathrm{mS} / \mathrm{cm}$ correlate with those found by Spanish authors for honeydew honey, produced from oak forests - $(0.9-1.0) \mathrm{mS} / \mathrm{cm}$ (11). Other authors also obtain similar conductivity results: Atanassova et al. (12) $0.961 \mathrm{mS} / \mathrm{cm}$, Čelechovská et al. (8) - 1.078 $\mathrm{mS} / \mathrm{cm}$, Przybyłowski et al. (13) - $0.96 \mathrm{mS} / \mathrm{cm}$.

The quantities of both abiogenic elements, lead and cadmium, in the samples from the three areas were similar. Fugure $\mathbf{2}$ shows the average values of both elements.

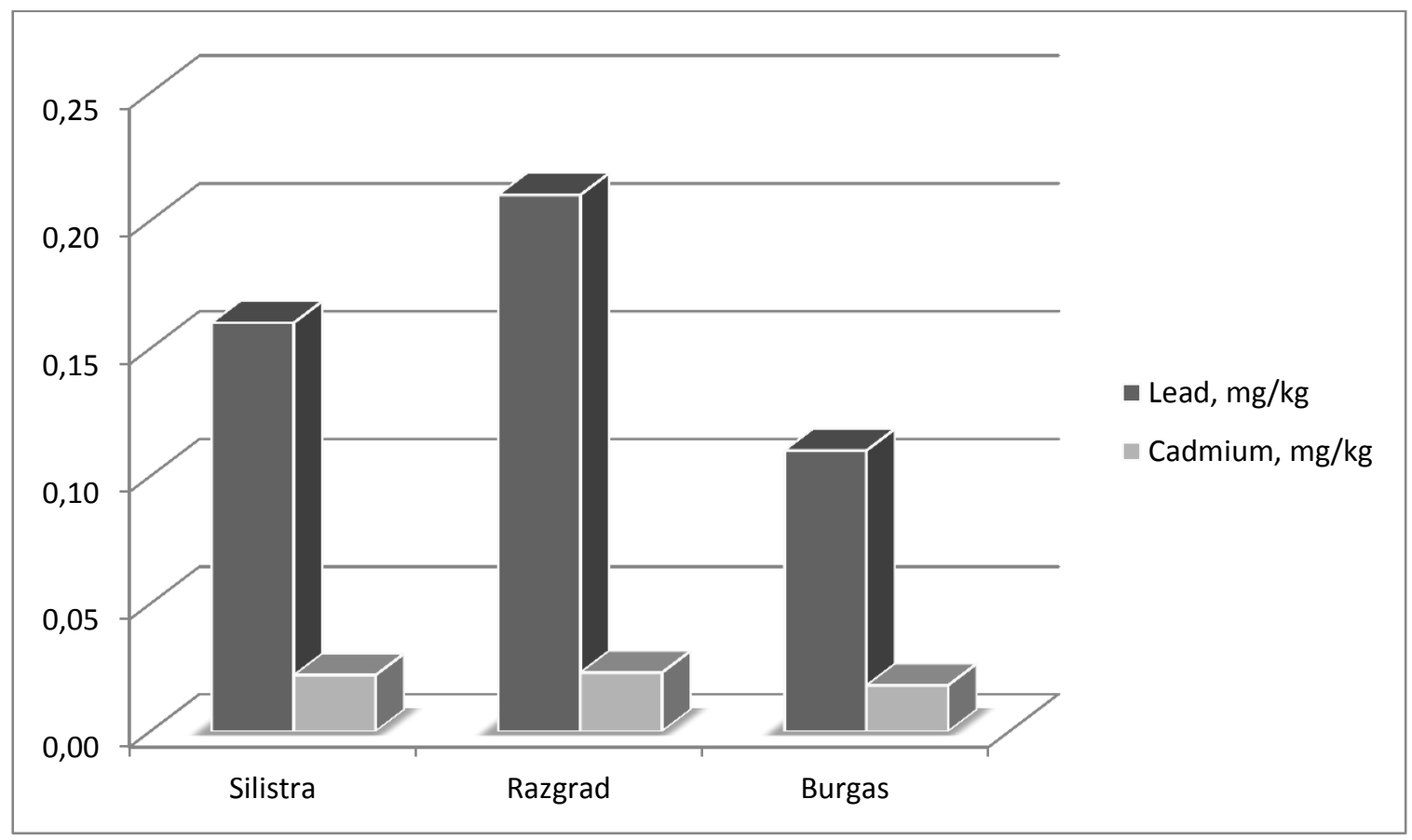

Figure 2. Content of lead and cadmium in honeydew honey from the regions of Silistra, Razgrad and Burgas

The highest average content of both elements was found in the samples from the area of Razgrad $-0.21 \mathrm{mg} / \mathrm{kg}(\mathrm{Pb})$ and $0.023 \mathrm{mg} / \mathrm{kg}$ (Cd). A study on Swiss honeydew honey (14) from 1986 founded lead content in the range of $(0.020-0.520) \mathrm{mg} / \mathrm{kg}$ and cadmium in the range of $(0.004-0.060) \mathrm{mg} / \mathrm{kg}$. The maximal values of both metals in the Swiss honeydew honey exceed the results for the areas, subject of our study.

Rusakova and Martynova (4) have found in various developed industrial areas of Russia and Ukraine lead values in the range of (0.296$0.593) \mathrm{mg} / \mathrm{kg}$, exceeding significantly the results that we obtained.

Other authors have identified lower values of both metals, compared with our values. In honeydew honey from Poland were found $0.027 \mathrm{mg} / \mathrm{kg}$ of cadmium and $0.037 \mathrm{mg} / \mathrm{kg}$ of lead respectively (13). In honeydew honey from Italy Pisani et al. (15) up to $0.147 \mathrm{mg} / \mathrm{kg}$ of lead content and up to $0.00347 \mathrm{mg} / \mathrm{kg}$ of cadmium content have identified. In Serbian honeydew honey the lead is $(0.1 \pm 0.07) \mathrm{mg} / \mathrm{kg}$ (16). A study on Bulgarian honeydew honey, conducted in 2008 by Yurukova et al. (17), founded less than $0.2 \mathrm{mg} / \mathrm{kg}$ of lead and less than $0.02 \mathrm{mg} / \mathrm{kg}$ of cadmium. A study, conducted in the period from 2006 to 2009 by Atanassova et al. (12), on Bulgarian honeydew honey, supplied by producers, has shown less than $0.08 \mathrm{mg} / \mathrm{kg}$ of lead content and less than $0.01 \mathrm{mg} / \mathrm{kg}$ of cadmium content.

The average contents of copper, zinc and iron in the samples from the three areas are shown on the graph in Figure 3.

The copper quantity in the samples from the three areas were very similar, the highest zinc content was found in the samples from Razgrad, and iron content was the highest in the samples from Silistra. We suppose that there is a relation with the different content of the elements in the soil of these areas. 


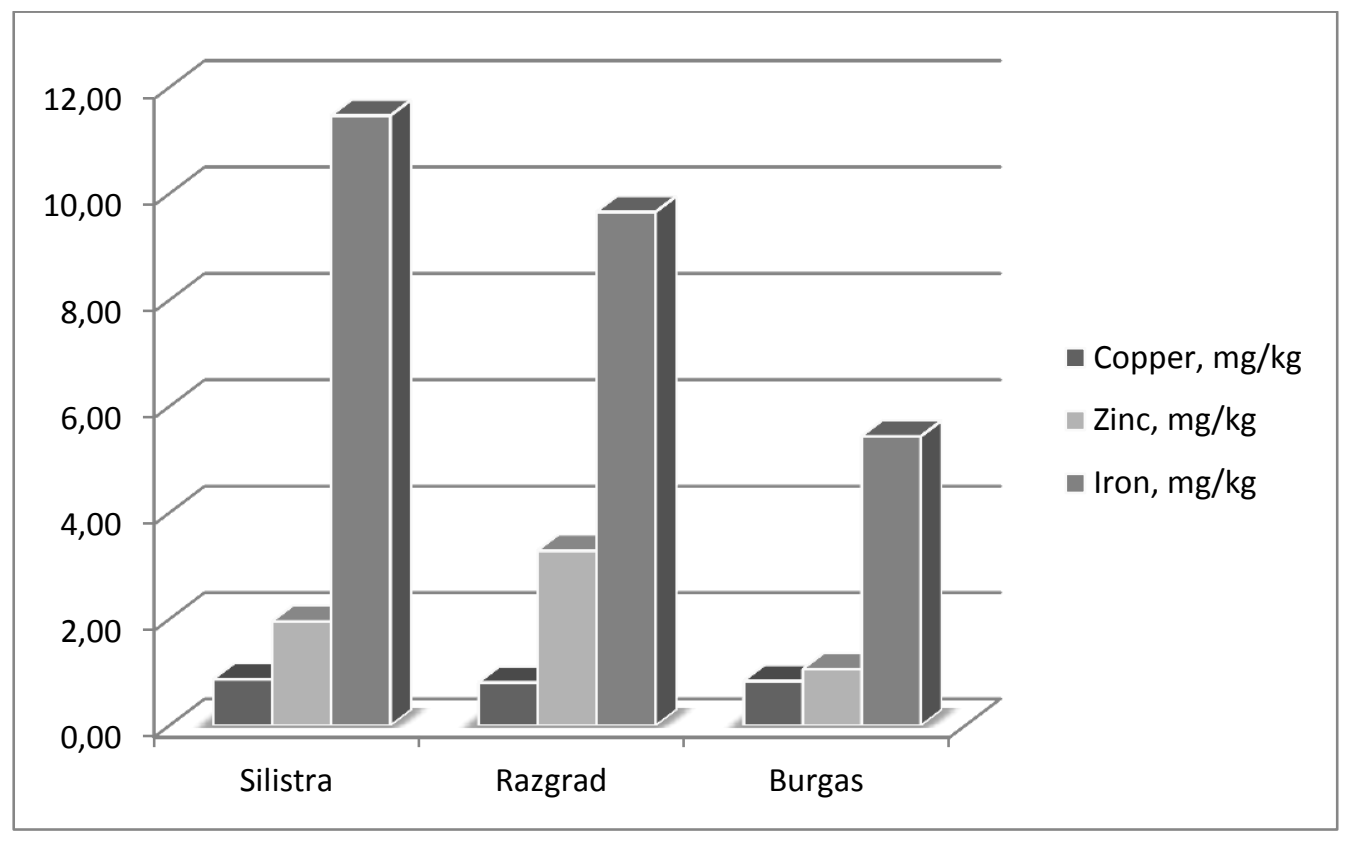

Figure 3. Copper, zinc and iron in honeydew honey from the regions of Silistra, Razgrad and Burgas

Our studies found copper content in the range of (0.81- 0.87$) \mathrm{mg} / \mathrm{kg}$. These data are similar to the results of other Bulgarian authors -0.45 $\mathrm{mg} / \mathrm{kg}$ (12) and $0.73 \mathrm{mg} / \mathrm{kg}$ (17). Serbian authors give lower values $-0.30 \mathrm{mg} / \mathrm{kg}(16)$, authors from New Zealand $-0.18 \mathrm{mg} / \mathrm{kg}$ (18), but studies in Italy present significantly higher values $-4.4 \mathrm{mg} / \mathrm{kg}(15)$.

Atanassova et al. (12) have found zinc content of $0.47 \mathrm{mg} / \mathrm{kg}$, and Yurukova et al. (17) - from $0.42 \mathrm{mg} / \mathrm{kg}$ to $4.64 \mathrm{mg} / \mathrm{kg}$. These data are similar to our results for honeydew honey from the Burgas area - from $0.63 \mathrm{mg} / \mathrm{kg}$ to 2.42 $\mathrm{mg} / \mathrm{kg}$. Similar to the results for zinc in the samples from the three areas are the results, determined by Pisani et al. (15) in honey from Italy $-1.87 \mathrm{mg} / \mathrm{kg}$, by Vanhanen et al. (18) in honey from New Zealand $-2.46 \mathrm{mg} / \mathrm{kg}$, and by Lachman et al. (19) for honeydew honey from Czech Republic - $2.51 \mathrm{mg} / \mathrm{kg}$. Bratu et al. (6) have determined $3.3 \mathrm{mg} / \mathrm{kg}$ of zinc in honey from Romania that matched the content, found for the Razgrad area $-3.29 \mathrm{mg} / \mathrm{kg}$.

The iron in the examined samples for the three areas varied from $5.44 \mathrm{mg} / \mathrm{kg}$ to $11.47 \mathrm{mg} / \mathrm{kg}$. The iron values from the study of Yurukova et al. (17) are in the range of $(1.83-13.1) \mathrm{mg} / \mathrm{kg}$, and are similar with the data, determined by us. Also the results from Italian authors are comparable with our results - the iron is in the range of $(7.07-13.7) \mathrm{mg} / \mathrm{kg}(15)$.

The average manganese and cobalt values, that we determined, are shown in Figure 4.

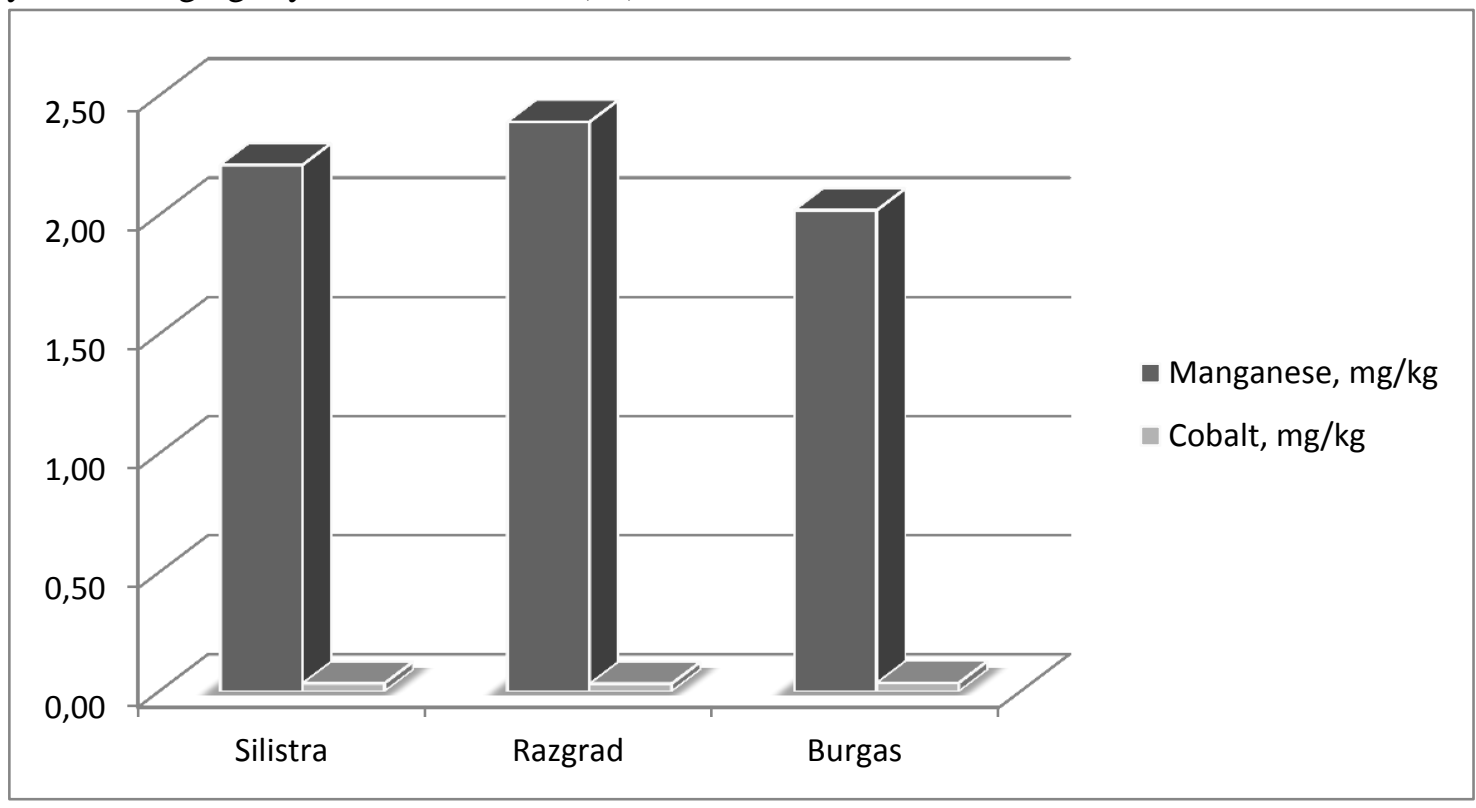

Figure 4. Manganese and cobalt in honeydew honey from the regions of Silistra, Razgrad and Burgas 
As shown, the values for the three areas are very similar - from $2.02 \mathrm{mg} / \mathrm{kg}$ to $2.39 \mathrm{mg} / \mathrm{kg}$ for manganese and from $0.032 \mathrm{mg} / \mathrm{kg}$ to 0.036 $\mathrm{mg} / \mathrm{kg}$ for cobalt. Other Bulgarian authors have determined significantly higher content of manganese $-12.7 \mathrm{mg} / \mathrm{kg}(12)$ and $12.3 \mathrm{mg} / \mathrm{kg}$ (17), and cobalt less than $0.02 \mathrm{mg} / \mathrm{kg}$ (17).

Italian authors have determined results, similar to ours $-1.70 \mathrm{mg} / \mathrm{kg}$ of manganese and 0.044 $\mathrm{mg} / \mathrm{kg}$ of cobalt (15). Czech authors have determined $7.01 \mathrm{mg} / \mathrm{kg}$ of manganese (19). Slovenian authors have stated very close value for manganese $-7.0 \mathrm{mg} / \mathrm{kg}$ (20). Vanhanen et al. (18) have determined significantly lower quantities of manganese in honeydew honey from New Zealand $-0.43 \mathrm{mg} / \mathrm{kg}$.

\section{CONCLUSION}

The authenticity of 44 studied samples of honeydew honey from the three monitored areas - Silistra, Razgrad and Burgas was demonstrated by determination of their conductivity.

The samples were analyzed for contents of lead, cadmium, copper, zinc, iron, manganese and cobalt. The average quantities of the abiogenic metals lead and cadmium were low, indicating minimal environmental contamination in the areas, where the honeydew honey has been produced.

The contents of copper, zinc and iron in the honeydew honey varied significantly. The probable cause is the different vegetation in the forests, where the honeydew honey has been produced, as well as the different quantities of these elements in the soil.

The quantities of cobalt and manganese, determined in honeydew honey, were similar or lower than the quantities, determined by other authors.

The honeydew honey study, conducted in Northeast and Southeast areas of Bulgaria, demonstrates that despite the existing probability of contamination with heavy metals, their content in the honey is well balanced, and does not pose a risk for the consumer.

\section{REFERENCES}

1. COUNCIL DIRECTIVE 2001/110/EC of 20 December 2001 relating to honey, 2001.

2. Младенов, Ст., Радосавович, М., Лечение с пчелни продукти -АПИТЕРАПИЯ• и основи на пчеларството, „Земиздат“ ЕООД, София, България, 1999.
3. Crane, E., Bees, honey and pollen as indicators of metals in the environment, Bee world, 65 (1): 47-49, 1984.

4. Русакова, Т. М., Мартынова, В. М., Окружающая среда и продукты пчёл, Пчеловодство, 1: 14-17, 1994.

5. Желязкова, Ив., Пчелните продукти като биоиндикатори в региони с различно антропогенно въздействие, Животновъдни науки, XLVIII, 1: 100106, 2011.

6. Bratu, I., Georgescu, C., Chemical contamination of bee honey - identifying sensor of the environment pollution, $J$. of Central European Agriculture, Vol. 6, № 1: 95-98, 2005.

7. Conti, M. E., Stripeikis, J., Campanella, L., Cucina, D., Tudino, M. B., Characterization of Italian honeys (Marche Region) on the basis of their mineral content and some typical quality parameters, Chemistry Central Journal, 1:14: 1-10, 2007.

8. Čelechovská, O., Vorlová, L., Groups of honey - physicochemical properties and heavy metals, Acta Vet. Brno, 70: 91-95, 2001.

9. БДС EN 14082. Храни. Определяне на следи от елементи. Определяне на олово, кадмий, цинк, хром, мед и желязо чрез атомно абсорбционна спектрометрия (AAS) след сухо опепеляване. Български Институт за Стандартизащия, София, България, 2003.

10. Bogdanov, S. (chairman, Switzerland), Lüllmann, C., (vice-chairman, Germany), Martin, P., (secretary, UK), Ohe, W., Russmann, H., Vorwohl, G., (Germany); Oddo, L. P., Sabatini, A.-G., Marcazzan, G. L., Piro, R., (Italy); Flamini, C., Morlot, M., Lheretier, J., Borneck, R., (France); Marioleas, P., Tsigouri, A., (Greece); Kerkvliet, J., (Netherlands), Ortiz, A., (Spain), Ivanov, T., (Bulgaria), D’Arcy, B., Mossel, B., (Australia) and Vit, P. (Venezuela), Honey quality, methods of analysis and international regulatory standards: review of the work of the international honey commission, Swiss Bee Research Centre, 2000.

11. Flores, M. S. R., Escuredo, O., Seijo, M. C., Assessment of physicochemical and antioxidant characteristics of Quercus pyrenaica honeydew honeys, Food Chemistry, 166: 101-106, 2015.

12. Atanassova, J., Yurukova, L., Lazarova, M., Pollen and Inorganic Characteristics of Bulgarian Unifloral Honeys, Czech $J$. Food Sci., Vol. 30, No. 6: 520-526, 2012. 
13. Przybyłowski, P., Wilczyńska, A., Honey as an environmental marker, Food Chemistry, 74: 289-291, 2001.

14. Bogdanov, S., Imdorf, A., Charrière, J.-D., Fluri, P., Kilchenmann, V., The contaminants of the bee colony, Swiss Bee Research Centre, 2003.

15. Pisani, A., Protano, G., Riccobono, F., Minor and trace elements in different honey types produced in Siena County (Italy), Food Chemistry, 107: 1553-1560, 2008.

16. Švarc-Gajić, J., Stojanović, Z., Direct Determination of Heavy Metals in Honey by Potentiometric Stripping Analysis, International $J$. of Food Processing Technology, 1: 1-6, 2014.

17. Yurukova, L., Atanassova, J., Lazarova, M., Preliminary study on honeydew honey from the Bulgarian market, Доклади на Българската академия на науките, Tome 61, BIOLOGIE, Botanique, № 11: 1433-1440, 2008.

18. Vanhanen, L. P., Emmertz, A., Savage, G. P., Mineral analysis of mono-floral New Zealand honey, Food Chemistry, 128: 236-240, 2011.

19. Lachman, J., Kolihová, D., Miholová, D., Košata, J., Titěra, D., Kult, K., Analysis of minority honey components: Possible use for the evaluation of honey quality, Food Chemistry, 101: 973-979, 2007.

20. Golob, T., Doberšek, U., Kump, P., Nečemer, M., Determination of trace and minor elements in Slovenian honey by total reflection X-ray fluorescence spectroscopy, Food Chemistry, 91: 593600, 2005. 